\title{
Comparison and Gas Loading Impact on Counter- and Concurrent Trickle-Bed Reactor Configurations for Ex-Situ Biomethanation
}

Michal Sposob ( $\square$ michal.sposob@nibio.no)

Norwegian Institute of Bioeconomy Research (NIBIO)

Radziah Wahid

Norwegian University of Life Sciences (NMBU)

\section{Research Article}

Keywords: Biogas upgrading, Carbon dioxide, Hydrogen, Methanobacterium, Methane

Posted Date: October 25th, 2021

DOl: https://doi.org/10.21203/rs.3.rs-989066/v1

License: (c) (i) This work is licensed under a Creative Commons Attribution 4.0 International License.

Read Full License 


\section{Abstract}

In this work, the two different configurations (counter- and concurrent) of laboratory scale trickle-bed reactors for ex-situ biomethanation were studied under continuous operation. Reactors operating at thermophilic conditions $\left(50^{\circ} \mathrm{C}\right.$ ) were fed with $\mathrm{H}_{2}$ and $\mathrm{CO}_{2}$ (ratio $4: 1$ ) while cow manure used as liquid phase and source of nutrients for microbiota. Studies were performed at the gas loading rate ranging from $10 \mathrm{~m}^{3} / \mathrm{m}^{3} / \mathrm{d}$ to $30 \mathrm{~m}^{3} / \mathrm{m}^{3} / \mathrm{d}$. The counter-current configuration performed better and had a higher stability compared to concurrent configuration. It achieved $96.1 \pm 2.5 \%$ of $\mathrm{CH}_{4}$ at gas loading 10 $\mathrm{m}^{3} / \mathrm{m}^{3} / \mathrm{d}$ compared to $86.4 \pm 3.3 \%$ of $\mathrm{CH}_{4}$ in concurrent at the same loading. At gas loadings $>15$ $\mathrm{m}^{3} / \mathrm{m}^{3} / \mathrm{d}$, the concurrent configuration had unstable performance (decreasing $\mathrm{CH}_{4}$ content), while the counter-current reactor exhibited stable performance even at the highest studied loading $\left(30 \mathrm{~m}^{3} / \mathrm{m}^{3} / \mathrm{d}\right)$, with $68.5 \pm 2.5 \%$ of $\mathrm{CH}_{4}$. The hydrogenotrophic methanogens such as Methanobacterium (45.7-64.9\%) and Methanothermobacter prevailed in both configurations.

\section{Introduction}

The role and share of renewable energy significantly increases in the recent years where the installed capacity of photovoltaics and wind power increased annually by $27 \%$ and $13 \%$ over the last 5 years ${ }^{1}$. Their rising presence increase the share of variable renewable electricity (VRE) due to the intermittent nature of these renewable energy sources ${ }^{2}$. The available storage capacity of energy production peaks is low and its further development is still too expensive ${ }^{3}$. Therefore, to stabilize the supply and demand for energy based on renewable energy sources the new solutions are needed to increase the stability of energy supply.

In the recent years anaerobic digestion (AD) plants producing biogas have been regarded as a vehicle for further integration of renewable energy and VRE serving for the energy storage through the Power-to-Gas (PtG) concept ${ }^{2}$. In this concept the VRE is used for methane $\left(\mathrm{CH}_{4}\right)$ production through the biomethanation (BM) process (Eq. 1) being the sustainable alternative for physicochemical biogas upgrading. Currently, biogas upgrading and particularly carbon dioxide $\left(\mathrm{CO}_{2}\right)$ removal from biogas is done through physicochemical methods such as water, chemical or physical scrubbing, pressure swing adsorption and membrane separation while water scrubbing is the most popular solution in Europe (around $40 \%$ of upgrading plants in Europe) ${ }^{4,5}$. However, the mentioned methods are expensive and not available for small-scale AD plants. Additionally, they require the removal/reduction of other contaminants such as hydrogen sulfide $\left(\mathrm{H}_{2} \mathrm{~S}\right)$ and siloxanes before $\mathrm{CO}_{2}$ removal ${ }^{6}$.

$$
\mathrm{CO}_{2}+4 \mathrm{H}_{2} \rightarrow \mathrm{CH}_{4}+2 \mathrm{H}_{2} \mathrm{O}
$$

The BM can be also performed through the biological process that gained a significant attention in the recent years. It is related to the lower technical requirements of biologically catalyzed processes (high 
temperature or pressure are not needed). During biological $\mathrm{BM}$, hydrogenotrophic methanogens utilize $\mathrm{CO}_{2}$ originating e.g., from biogas simultaneously with hydrogen $\left(\mathrm{H}_{2}\right)$ generated from VRE to produce $\mathrm{CH}_{4}$. This process can be performed either in-situ (direct $\mathrm{H}_{2}$ injection to the $A D$ ) or ex-situ $\left(\mathrm{H}_{2}\right.$ with $\mathrm{CO}_{2} /$ biogas are injected into the separate unit) ${ }^{7}$. The ex-situ concept gives more flexibility, stability compared to insitu $\mathrm{BM}^{8}$. The ex-situ $\mathrm{BM}$ can be performed in different reactor configurations and based on recent literature the use of trickle-bed reactor (TBR) is the most promising. The TBR configuration provides a large contact area between biofilm and gas phase, which enhance the conversion of $\mathrm{H}_{2}$ and $\mathrm{CO}_{2}$ into $\mathrm{CH}_{4}$ and mitigate the problem of $\mathrm{H}_{2}$ solubility ${ }^{9}$.

In TBR, the $\mathrm{CO}_{2}$ /biogas and $\mathrm{H}_{2}$ are introduced either at the reactor bottom (counter-current) or top (concurrent) through the packing material (Fig. 1). The previous studies on ex-situ BM using TBR were performed mostly on counter-current configurations while scarce literature comparing these two configurations is available ${ }^{10,11}$. To our knowledge, only one study performed by Porté et al. (2019) reported comparable results at an influent gas loading rate of $11.6 \mathrm{~m}^{3} / \mathrm{m}^{3} / \mathrm{d}$ for concurrent $(97.6 \%$ of $\left.\mathrm{CH}_{4}\right)$ and counter-current $\left(97.8 \%\right.$ of $\left.\mathrm{CH}_{4}\right)$ configurations filled with glass rings as packing material. However, the performed comparisons were performed on limited variation of used packing materials and low gas loading rates.

Therefore, in the present work, the performance of counter- and concurrent TBRs for ex-situ BM were compared using biocarriers at the laboratory-scale. The objective of this study was to evaluate the impact of gas loading rate (from 10 up to $30 \mathrm{~m}^{3} / \mathrm{m}^{3} / \mathrm{d}$ ) on $\mathrm{CH}_{4}$ production through hydrogenotrophic methanogenesis under thermophilic conditions $\left(50^{\circ} \mathrm{C}\right)$. Additionally, the composition of microbial communities in the liquid phase of TBR was analysed.

\section{Materials And Methods}

\subsection{Inoculum and enrichment}

The filtered cow manure $(200 \mu \mathrm{m})$ was used as the inoculum and liquid phase in this work (TS $=5.2 \pm$ $0.1 \%, \mathrm{VS}=3.4 \pm 0.1 \%, \mathrm{pH}=7.7) .150 \mathrm{~mL}$ of filtered cow manure was inoculated to the reactors at the beginning of the experiment to occupy the space below packing material at the TBR bottom (Fig. 1). For enrichment of microbiota, inoculum was recirculated continuously through TBR for $30 \mathrm{~min}$ (flow $=122$ $\mathrm{mL} / \mathrm{min}$ ) with substrate gas supply on. Subsequently, the acclimatization period was started under the conditions as experimental (described in Section 2.2.). The reactors fed $\mathrm{CO}_{2}$ and $\mathrm{H}_{2}$ achieved stable $\mathrm{CH}_{4}$ production after around two weeks at gas loading of $10 \mathrm{~m}^{3} / \mathrm{m}^{3} / \mathrm{d}$ (the data on acclimatization period is not included in this work).

\subsection{Experimental setup and feeding plan}


The two laboratory-scale TBRs made of glass with working volume $815 \mathrm{~mL}$ filled $145 \mathrm{~g}$ of biocarrier HEL$X$ (HXF13KLL+; surface area: $955 \mathrm{~m}^{2} / \mathrm{m}^{3}$ ) were used in this work. Substrate gas was introduced at the bottom (counter-current) or top (concurrent) of the reactor (Fig. 1). The gas flow was controlled by separate gas flow meters for $\mathrm{CO}_{2}$ and $\mathrm{H}_{2}$ at the volumetric ratio 1:4 (Alicat Scientific). Temperature in the reactors was maintained stable at thermophilic conditions $\left(50 \pm 1^{\circ} \mathrm{C}\right)$ by the water jacket using the water bath (VWR). During experimental period, recirculation was performed for $20 \mathrm{~min}$ per day in 20 occasions (1 minute each) equally divided over 24 hours. Recirculation was adjusted and kept stable at $122 \mathrm{~mL} / \mathrm{min}$ giving recirculation ratio of $3 \mathrm{~L} / \mathrm{L} / \mathrm{d}$. The liquid was regularly exchanged during the experiment (every 5 days) to avoid the dilution of nutrients in the liquid phase. During the exchange, the $50 \mathrm{~mL}$ of liquid phase was taken out and replaced with pasteurized cow manure giving the hydraulic retention time (HRT) of around $3 \mathrm{~d}$. The excess of liquid phase was also removed at the same frequency. Further details on the feeding plan are given in Table 1.

Table 1

Feeding plan.

\begin{tabular}{|c|c|c|c|c|c|c|}
\hline \multirow{2}{*}{$\begin{array}{l}\text { Period } \\
\text { (days) }\end{array}$} & \multicolumn{3}{|c|}{ Counter-current } & \multicolumn{3}{|l|}{ Concurrent } \\
\hline & $\begin{array}{l}\text { Gas loading } \\
\left(\mathrm{m}^{3} / \mathrm{m}^{3} / \mathrm{d}\right)\end{array}$ & $\begin{array}{l}\mathrm{CO}_{2} \text { flow } \\
\left(\mathrm{cm}^{3} / \mathrm{min}\right)\end{array}$ & $\begin{array}{l}\mathrm{H}_{2} \text { flow } \\
\text { (cm } \mathrm{cm}^{3} / \mathrm{min} \text { ) }\end{array}$ & $\begin{array}{l}\text { Gas loading } \\
\left(\mathrm{m}^{3} / \mathrm{m}^{3} / \mathrm{d}\right)^{*}\end{array}$ & $\begin{array}{l}\mathrm{CO}_{2} \text { flow } \\
\left(\mathrm{cm}^{3} / \mathrm{min}\right)\end{array}$ & $\begin{array}{l}\mathrm{H}_{2} \text { flow } \\
\left(\mathrm{cm}^{3} / \mathrm{min}\right)\end{array}$ \\
\hline $1-10$ & 10 & 1.13 & 4.53 & 10 & 1.13 & 4.53 \\
\hline $11-25$ & 20 & 2.26 & 9.06 & 20 & 2.26 & 9.06 \\
\hline $26-35$ & 25 & 2.83 & 11.32 & 15 & 1.70 & 6.79 \\
\hline $36-45$ & 30 & 3.4 & 13.58 & 20 & 2.26 & 9.06 \\
\hline
\end{tabular}

\subsection{Analytical methods}

The samples of effluent gas were analyzed daily for gas composition $\left(\mathrm{CH}_{4}, \mathrm{CO}_{2}\right)$ using gas chromatography (GC; Agilent 3000A Micro GC) using helium as carrier gas. The GC was equipped with thermal conductivity detector (TCD). The presence of $\mathrm{H}_{2}$ in the gas was derived by the mass balance. The liquid samples extracted from the reactors every 5 days have been analyzed for volatile fatty acids (VFAs) presence using high performance liquid chromatography (HPLC; Thermo Scientific UltiMate 3000) using $4 \mathrm{mM} \mathrm{H}_{2} \mathrm{SO}_{4}$ as the eluent. The HPLC was equipped with UV detector. Alkalinity of liquid samples was measured using titration method with $\mathrm{H}_{2} \mathrm{SO}_{4}$ (Titroline 7000) according to the Standard Methods ${ }^{13}$. Additionally, daily monitoring of $\mathrm{pH}$ in liquid phase was performed using $\mathrm{pH}$ electrodes (Vernier). Due to the reactor volume, gas was collected into the multi-layer gas sampling bags (RASTEK), while the volume collected in time was measured using gas syringe (Popper \& Sons).

The gas contraction was calculated based on the Eq. 2 where $\mathrm{CO}_{2 \text { (inf) }}$ and $\mathrm{H}_{2 \text { (inf) }}$ represent the volume of

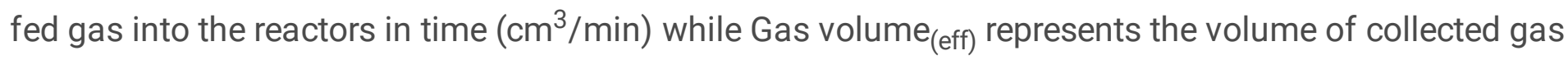
at the same time. 


\subsection{Molecular methods}

$$
\text { Contraction }(\%)=\frac{\text { Gasvolume }_{(\text {eff })}}{\mathrm{CO}_{2(\text { inf })}+H_{2(\text { inf })}} \cdot 100 \%
$$

\subsubsection{Samples collection, extraction, and library preparation}

Samples collection was performed after each liquid exchange (every 5 days) while at the end of the experiment 5 samples from counter-current (from day 1, 10, 25, 30, and 45) and 7 from concurrent reactor (from day $1,10,15,20,25,35$, and 45 ) were selected for molecular analysis.

DNA extraction was performed using a slightly modified version of the standard protocol for FastDNA Spin kit for Soil (MP Biomedicals): $500 \mu \mathrm{L}$ of sample, $480 \mu \mathrm{L}$ sodium phosphate buffer and $120 \mu \mathrm{L}$ MT buffer were added to a Lysing Matrix $E$ tube. Bead beating was performed at $6 \mathrm{~m} / \mathrm{s}$ for $4 \times 40 \mathrm{~s}^{14}$. TapeStation 2200 was used for electrophoresis while Genomic DNA ScreenTapes (Aligent) were used to validate product size and purity of a subset of DNA extracts. DNA concentration was measured using Qubit dsDNA HS/BR Assay kit (Thermo Fisher Scientific).

Archaea and bacteria, 16S rRNA gene variable region V4 sequencing libraries were prepared based on an Illumina protocol. Up to $10 \mathrm{ng}$ of extracted DNA was used as template for PCR. Each PCR reaction $(25 \mu \mathrm{L})$ contained $(12.5 \mu \mathrm{L})$ PCRBIO Ultra mix and $400 \mathrm{nM}$ of each forward and reverse tailed primer mix. Duplicate PCR reactions were performed. The forward and reverse, tailed primers targeted archaea and bacteria, 16S rRNA variable region V4: [515FB] GTGYCAGCMGCCGCGGTAA and [806RB] GGACTACNVGGGTWTCTAAT ${ }^{15}$. The resulting amplicon libraries were purified using the standard protocol for CleanPCR SPRI beads (CleanNA). DNA concentration was measured using Qubit dsDNA HS Assay kit (Thermo Fisher Scientific). Sequencing libraries were prepared from the purified amplicon libraries using a second PCR. Each PCR reaction $(25 \mu \mathrm{L})$ contained PCRBIO HiFi buffer (1x), PCRBIO HiFi Polymerase (1 U/reaction) (PCRBiosystems), adaptor mix ( $400 \mathrm{nM}$ of each forward and reverse) and up to $10 \mathrm{ng}$ of amplicon library template. PCR conditions: $95^{\circ} \mathrm{C}$ for $2 \mathrm{~min}, 8$ cycles of amplification $\left(95^{\circ} \mathrm{C}\right.$ for $20 \mathrm{~s}, 55^{\circ} \mathrm{C}$ for $30 \mathrm{~s}, 72^{\circ} \mathrm{C}$ for $60 \mathrm{~s}$ ) and a final elongation at $72^{\circ} \mathrm{C}$ for 5 min.

\subsubsection{DNA sequencing and bioinformatics}

The purified sequencing libraries were pooled in equimolar concentrations and diluted to $2 \mathrm{nM}$. The samples were paired-end sequenced ( $2 \times 300$ bp) on a MiSeq (Illumina) using a MiSeq Reagent kit v3 (Illumina) following the standard guidelines for preparing and loading samples on the MiSeq. The trimmed reads (using Trimmomatic v.0.32) were dereplicated and formatted for use in the UPARSE workflow ${ }^{16}$. Taxonomy was assigned using the RDP classified as implemented in the script in QIIME and the SILVA database ${ }^{17-19}$.

\section{Results And Discussion}




\subsection{Reactors performance and comparison \\ 3.1.1. Counter-current TBR}

The counter-current configuration achieved the highest effluent $\mathrm{CH}_{4}$ content and could treat higher gas loadings in a stable manner compared to concurrent configuration (Fig. 2 (a) and Table 2). Effluent gas had a $\mathrm{CH}_{4}$ content $>95 \%$ at the gas loading of $10 \mathrm{~m}^{3} / \mathrm{m}^{3} / \mathrm{d}(96.1 \pm 2.5 \%)$ and low $\mathrm{CO}_{2}$ and $\mathrm{H}_{2}$ content, 2.2 $\pm 1.2 \%$ and $1.7 \pm 1.3 \%$, respectively. The biomethane quality obtained during this work typically allows for grid injection depending on the national quality standards ${ }^{20}$. Similar effluent $\mathrm{CH}_{4}$ content was previously reported in other counter-current TBR studies such as Burkhardt et al. (2015) and Strübing et al. (2019). Although, the operational conditions between previous studies and this study significantly differ. The high $\mathrm{CH}_{4}$ in this work was obtained without external $\mathrm{pH}$ stabilization and by using natural liquid nutrient source as cow manure.

At $20 \mathrm{~m}^{3} / \mathrm{m}^{3} / \mathrm{d}$ gas loading rate, the effluent $\mathrm{CH}_{4}$ content decreased $<90 \%(87.5 \pm 3.2 \%)$, although the production was characterized as stable. The $\mathrm{CO}_{2}$ and $\mathrm{H}_{2}$ content in the effluent gas increased nearly 2.5 $(5.3 \pm 0.7 \%)$ and $4.0(7.2 \pm 3.2 \%)$ times compared to lower gas loading.

Due to the stable $\mathrm{CH}_{4}$ production, the gas loading was increased in this work further to 25 and finally to $30 \mathrm{~m}^{3} / \mathrm{m}^{3} / \mathrm{d}$. Subsequent gas loading increase decreased the effluent $\mathrm{CH}_{4}$ content to $<80 \%$ and $<70 \%$, respectively. Although, the process was still characterized by stable $\mathrm{CH}_{4}$ production. This indicates the possibility for process optimization. It can be potentially achieved by changes in operational conditions such as recirculation rate or HRT at higher gas loadings to increase the effluent $\mathrm{CH}_{4}$ content.

At the highest gas loading $\left(30 \mathrm{~m}^{3} / \mathrm{m}^{3} / \mathrm{d}\right), \mathrm{H}_{2}$ share in effluent gas was up to $27.9 \%$ while $\mathrm{CO}_{2}$ was up to $12.5 \%$. It was found that the ratio of $\mathrm{H}_{2} / \mathrm{CO}_{2}$ in the effluent gas increases with increasing gas loading reaching from $0.8: 1\left(10 \mathrm{~m}^{3} / \mathrm{m}^{3} / \mathrm{d}\right)$ to $1.9: 1\left(30 \mathrm{~m}^{3} / \mathrm{m}^{3} / \mathrm{d}\right)$. The increase in effluent $\mathrm{H}_{2} / \mathrm{CO}_{2}$ ratio that is near the feeding ratio (4:1) can imply that the reactor is approaching the overload status where the applied gas loading is too high to be handled by the biofilm developed on packing material.

\subsubsection{Concurrent TBR}

The concurrent configuration had the same gas loading as a starting point as the counter-current reactor $\left(10 \mathrm{~m}^{3} / \mathrm{m}^{3} / \mathrm{d}\right)$. However, the effluent gas had a nearly $10 \%$ lower $\mathrm{CH}_{4}$ content ( $86.4 \pm 3.3 \%$ ) compared to counter-current configuration. The average, $\mathrm{H}_{2}$ and $\mathrm{CO}_{2}$ content were $5.3 \pm 0.3 \%$ and $8.4 \pm 3.2 \%$, respectively.

Previous studies on concurrent configuration reported higher $\mathrm{CH}_{4}$ content at similar gas loadings compared to this study, although, they used different packing material (polyurethane foam filling) for their studies ${ }^{23,24}$. The selection of packing material is one of critical parameters for biofilm development. 
The main criteria used for its selection is the large surface area. The surface area of packing material used in this study was around $955 \mathrm{~m}^{2} / \mathrm{m}^{3}$ while the polyurethane foam has a lower surface area of 560 $580 \mathrm{~m}^{2} / \mathrm{m}^{3}$. However, the applied material in this work having a larger surface area, did not yield in better results compared to previous studies on concurrent configuration.

The way of gas introduction was found as a very important parameter for biofilm development in TBR. We observed, that when the gas is introduced from the reactor top to the bottom (concurrent) it removes the liquid from the packing material much faster compared to the counter-current configuration. Since the recirculation in this work was performed non-continuously (20 min per 24 hours) it could lead to faster biofilm drying and poor access to the nutrients present in liquid phase. This could significantly hinder and slow down the biofilm development, especially when the packing materials of open structure are used in TBR.

After operation at $10 \mathrm{~m}^{3} / \mathrm{m}^{3} / \mathrm{d}$ the gas loading was increased to $20 \mathrm{~m}^{3} / \mathrm{m}^{3} / \mathrm{d}$ which led to a significant performance decrease and reactor instability. The $\mathrm{CH}_{4}$ content was $<50 \%(47.1 \pm 9.6 \%)$ while the effluent $\mathrm{H}_{2} / \mathrm{CO}_{2}$ ratio was 2.8:1 being the highest between all studied cases. $\mathrm{H}_{2}$ content in the effluent gas was up to $53.0 \%$ while $\mathrm{CO}_{2}$ up to $19.6 \%$. The $\mathrm{CH}_{4}$ production was unstable during this phase where a clear decrease of $\mathrm{CH}_{4}$ production was observed after each liquid exchange (indicated as red inverted triangles at Fig. 2). The three clear phases can be distinguished (Fig. 2 (b), days 11-15, 16-20, and 21-25). Following each liquid exchange, the reactor performance was improved, producing $\mathrm{CH}_{4}$ content of around $60 \%$, which then decrease approximately $10 \%$ per day until next liquid exchange. The obtained results indicate a significant change in the metabolism inside the TBR, reactor overloading, and lower flexibility of concurrent configuration compared to counter-current.

Due to the low $\mathrm{CH}_{4}$ production at $20 \mathrm{~m}^{3} / \mathrm{m}^{3} / \mathrm{d}$, the gas loading rate was reduced to $15 \mathrm{~m}^{3} / \mathrm{m}^{3} / \mathrm{d}$ to increase the $\mathrm{CH}_{4}$ content in produced gas. Reduced gas loading improved performance increasing the $\mathrm{CH}_{4}$ content to $83.1 \pm 3.4 \%$. Interestingly, at this phase, the effluent $\mathrm{H}_{2} / \mathrm{CO}_{2}$ ratio was even lower $(0.9: 1)$ than at gas loading of $10 \mathrm{~m}^{3} / \mathrm{m}^{3} / \mathrm{d}(1.6: 1)$. It indicates a slightly better biofilm development inside the reactor that was further confirmed by the second gas loading increase to $20 \mathrm{~m}^{3} / \mathrm{m}^{3} / \mathrm{d}$. At the second attempt at $20 \mathrm{~m}^{3} / \mathrm{m}^{3} / \mathrm{d}$ the obtained results were significantly better compared to the first attempt. The $\mathrm{CH}_{4}$ content of $75.9 \pm 7.5 \%$ was obtained, being 1.6 higher compared to the first attempt. However, the $\mathrm{CH}_{4}$ production was characterized as unstable, where the $\mathrm{CH}_{4}$ content was dependent on the liquid phase exchanges. The results implies that the concurrent configuration was characterized by worst biofilm development compared to the counter-current configuration

\subsection{Substrates metabolism and liquid phase}

\subsection{1. $\mathrm{pH}$}


Due to the lack of solids supplementation during ex-situ BM, nutrient supply becomes necessary ${ }^{25}$. The non-enriched cow manure was used as the liquid nutrient and inoculum in this work that had an initial $\mathrm{pH}$ of 7.7. After its introduction to both TBRs, the $\mathrm{pH}$ of the liquid increased for most of the time above 8.0. It can be related to the partial dissolving of fed $\mathrm{CO}_{2}$ into liquid phase as $\mathrm{HCO}_{3}{ }^{-}\left(\mathrm{pK}_{\mathrm{a}}=6.85\right)$. The $\mathrm{pH}$ values in the counter-current reactor ranged from 7.80 to 8.61 and 7.87 to 8.55 for the concurrent reactor. Similar values were reported by Porté et al. (2019) that used digestate from a biogas plant as a liquid nutrient source reached pH up to 8.6. Additionally, Dahl Jønson et al. (2020) reached pH up to of 8.5 using cow manure. The values $>8.6$ were indicated as above the optimum level for methanogens, however, no further $\mathrm{pH}$ increase was observed, and therefore no $\mathrm{pH}$ adjustments were applied in this work.

Further increase in gas loading that led to the lower $\mathrm{CH}_{4}$ production also decreased the $\mathrm{pH}$ in the liquid phase of TBRs. The lowest average $\mathrm{pH}$ for counter-current reactor was $7.9 \pm 0.1$ at gas loading rate of 30 $\mathrm{m}^{3} / \mathrm{m}^{3} / \mathrm{d}$. The $\mathrm{CH}_{4}$ content in the effluent gas decreased as the $\mathrm{pH}$ decreased (Fig. 3). Strübing et al. (2017) mentioned potential reasons for $\mathrm{pH}$ decline during biomethanation such as buffer capacity reduction due to $\mathrm{H}_{2} \mathrm{O}$ production and homoacetogenesis. Although, in this work, the sharper decrease was observed for concurrent configuration where the $\mathrm{CH}_{4}$ content $<60 \%$ was achieved already at $\mathrm{pH} 8.2$, such low $\mathrm{CH}_{4}$ content was reported only once for counter-current configuration at $\mathrm{pH}$ 7.9. These observations may indicate the higher performance vulnerability of this configuration, as well as possible differences in the microbiology of these configurations.

In general, either mineral media or $\mathrm{pH}$ maintaining systems are used in TBR studies to maintain the process at certain $\mathrm{pH}$ range. To achieve the optimal performance of $\mathrm{TBR} \mathrm{pH}$ values below reported in this work were used. For example, the efficient $\mathrm{CH}_{4}$ production was reported e.g., at $\mathrm{pH}$ range 6.8-7.7 yielding in $\mathrm{CH}_{4}$ content $>95 \%{ }^{11,21}$. Although, our results indicate the advantage of using cow manure as a suitable source of liquid phase for ex-situ biomethanation that does not require $\mathrm{pH}$ maintenance or mineral supplementation.

\subsubsection{Acetic acid and alkalinity}

The reactor liquid phase parameters such as alkalinity and acetic acid were influenced by different gas loadings and reactor configurations (Fig. 4). A significant difference in alkalinity level and acetic acid presence was found in both reactors.

The alkalinity and acetic acid decreased over time in the counter-current reactor. Acetic acid presence decreased threefold from 27.7 to $9.2 \mathrm{mg} / \mathrm{L}$ even when the liquid phase was periodically exchanged. Similarly, alkalinity decreased 1.6 times from 4051.5 to $2508.6 \mathrm{mgCaCO}_{3} / \mathrm{L}$. This trend can be attributed to the liquid phase dilution, due to the $\mathrm{H}_{2} \mathrm{O}$ production (second product of hydrogenotrophic methanogenesis, Eq. 1). At higher gas loadings, the volume of produced $\mathrm{H}_{2} \mathrm{O}$ is increasing that ends up in the liquid phase of TBR. We observed that the level of liquid phase at the reactor bottom increases, especially at gas loadings $>10 \mathrm{~m}^{3} / \mathrm{m}^{3} / \mathrm{d}$. 
To equalize the liquid level in TBR, the excess of liquid was removed at the end of each experimental period. For the counter-current reactor low volumes of excess liquid ca. 30, 50 and $70 \mathrm{~mL}$ were removed after applied gas loadings of 20,25 and $30 \mathrm{~m}^{3} / \mathrm{m}^{3} / \mathrm{d}$, respectively. It can be hypothesized that without excess liquid removal, the dilution would be more severe, and concentrations of acetic acid and alkalinity will be even lower, leading to the process destabilization.

In concurrent configuration, the unstable $\mathrm{CH}_{4}$ production was accompanied by unstable levels of acetic acid and alkalinity. The acetic acid concentrations were found higher than in the counter-current reactor and varied from 33.1 to $63.8 \mathrm{mg} / \mathrm{L}$. The results were consistent with Porte et al. (2019), which observed that the counter-current configuration could affect the process due to the densities of gases passing through the reactor. $\mathrm{H}_{2}$ has a much lower density than $\mathrm{CH}_{4}$ and $\mathrm{CO}_{2}$, and a downward flow could result in a higher $\mathrm{H}_{2}$ partial pressure in the liquid than an upflow process. The alkalinity in concurrent configuration varied from 2775.3 to $3642.0 \mathrm{mgCaCO}_{3} / \mathrm{L}$. Interestingly, the highest levels of acetic acid at $20 \mathrm{~m}^{3} / \mathrm{m}^{3} / \mathrm{d}$ (days 11-25) occurred at the same time as the lowest content of $\mathrm{CH}_{4}$ (average: $47.1 \pm 9.6 \%$ ) and the lowest $\mathrm{pH}$ (average: $8.1 \pm 0.1$ ) were obtained. The declining $\mathrm{pH}$ can be correlated to acetate accumulation, as similarly observed by e.g., Kougias et al. (2017). In this work, other VFAs were also measured, however, their concentrations did not exceed $10 \mathrm{mg} / \mathrm{L}$ for both configurations. Variability in acetic acid presence can indicate changes in substrates metabolism and possible homoacetogenesis conducted by autotrophic acetogenic microorganisms (Eq. 3). The fed substrates could be at some degree utilized to produce acetate instead of $\mathrm{CH}_{4}{ }^{27}$. Consequently, alkalinity reaches its lowest level at the highest acetic acid presence and the lowest $\mathrm{CH}_{4}$ production.

$$
2 \mathrm{CO}_{2}+4 \mathrm{H}_{2} \rightarrow \mathrm{CH}_{3} \mathrm{COOH}+2 \mathrm{H}_{2} \mathrm{O}
$$

The free-energy $\left(\Delta \mathrm{G}^{0}\right)$ of hydrogenotrophic methanogenesis is larger (-135.0) than homoacetogenesis $(-104.0)$, therefore, homoacetogenesis is considered thermodynamically unfavorable. However, homoacetogens have been shown to outcompete hydrogenotrophic methanogens at lower temperatures and also when methanogenic activity is inhibited 27,28 . Their presence was previously reported at different mesophilic, thermophilic and hyperthermophilic conditions such as AD or dark fermentation ${ }^{29}$. Therefore, potentially under unstable $\mathrm{CH}_{4}$ production due to reactor overloading, homoacetogens found a niche for their activity leading to higher acetic acid presence in the liquid phase of concurrent TBR.

The increase in liquid level was also observed at the concurrent configuration, however, only after gas loadings of 15 and $20 \mathrm{~m}^{3} / \mathrm{m}^{3} / \mathrm{d}$ (days 36-45) where ca. $50 \mathrm{~mL}$ of excess liquid phase was removed 
Table 2. Results summary from operation of counter- and concurrent TBRs.

\begin{tabular}{|c|c|c|c|c|c|c|c|c|c|c|c|}
\hline \multicolumn{12}{|c|}{ Counter-current } \\
\hline \multirow[b]{2}{*}{ Period (days) } & \multirow[b]{2}{*}{$\begin{array}{l}\text { Gas loading } \\
\left(\mathrm{m}^{3} / \mathrm{m}^{3} / \mathrm{d}\right)\end{array}$} & \multicolumn{3}{|c|}{ Substrates removal } & \multicolumn{4}{|c|}{ Effluent gas composition } & \multicolumn{3}{|c|}{ Liquid phase } \\
\hline & & $\mathbf{H}_{2}(\%)$ & $\begin{array}{l}\mathrm{CO}_{2} \\
(\%)\end{array}$ & $\begin{array}{c}\text { Contraction of } \\
\text { gas (\%) }\end{array}$ & $\begin{array}{l}\mathrm{CH}_{4} \\
(\%)\end{array}$ & $\mathrm{CO}_{2}(\%)$ & $\mathrm{H}_{2}(\%)$ & $\mathrm{H}_{2} / \mathrm{CO}_{2}$ & $\mathrm{pH}$ & $\begin{array}{c}\text { Acetic acid } \\
(\mathrm{mg} / \mathrm{L})\end{array}$ & $\begin{array}{c}\text { Alkalinity (mg } \\
\left.\mathrm{CaCO}_{3} / \mathrm{L}\right)\end{array}$ \\
\hline $1-10$ & 10 & 99.6 & 97.7 & $20.1 \pm 2.5$ & $\begin{array}{c}96.1 \pm \\
2.5\end{array}$ & $2.2 \pm 1.2$ & $1.7 \pm 1.3$ & 0.8 & $8.5 \pm 0.0$ & $27.3 \pm 0.8$ & $4099.2 \pm 79.7$ \\
\hline $11-25$ & 20 & 97.7 & 93.1 & $25.9 \pm 2.2$ & $\begin{array}{c}87.5 \pm \\
3.2\end{array}$ & $5.3 \pm 0.7$ & $7.2 \pm 3.2$ & 1.4 & $8.3 \pm 0.1$ & $21.8 \pm 2.3$ & $3596.4 \pm 149.5$ \\
\hline $26-35$ & 25 & 95.2 & 87.9 & $30.1 \pm 1.0$ & $\begin{array}{c}79.2 \pm \\
2.3 \\
\end{array}$ & $8.1 \pm 0.5$ & $12.7 \pm 2.1$ & 1.6 & $8.1 \pm 0.0$ & $15.1 \pm 3.9$ & $2809.4 \pm 93.6$ \\
\hline $36-45$ & 30 & 91.5 & 82.4 & $32.7 \pm 2.0$ & $\begin{array}{c}68.5 \pm \\
4.5\end{array}$ & $10.8 \pm 0.9$ & $20.7 \pm 3.7$ & 1.9 & $7.9 \pm 0.1$ & $8.9 \pm 0.8$ & $2483.5 \pm 35.6$ \\
\hline \multicolumn{12}{|c|}{ Concurrent } \\
\hline \multirow[b]{2}{*}{ Period (days) } & \multirow{2}{*}{$\begin{array}{l}\text { Gas loading } \\
\left(\mathrm{m}^{3} / \mathrm{m}^{3} / \mathrm{d}\right)\end{array}$} & \multicolumn{3}{|c|}{ Substrates removal } & \multicolumn{4}{|c|}{ Effluent gas composition } & \multicolumn{3}{|c|}{ Liquid phase } \\
\hline & & $\mathrm{H}_{2}(\%)$ & $\begin{array}{l}\mathrm{CO}_{2} \\
(\%)\end{array}$ & $\begin{array}{c}\text { Contraction of } \\
\text { gas (\%) }\end{array}$ & $\begin{array}{l}\mathrm{CH}_{4} \\
(\%)\end{array}$ & $\mathrm{CO}_{2}(\%)$ & $\mathrm{H}_{2}(\%)$ & $\mathrm{H}_{2} / \mathrm{CO}_{2}$ & $\mathrm{pH}$ & $\begin{array}{c}\text { Acetic acid } \\
(\mathrm{mg} / \mathrm{L})\end{array}$ & $\begin{array}{c}\text { Alkalinity (mg } \\
\left.\mathrm{CaCO}_{3} / \mathrm{L}\right)\end{array}$ \\
\hline $1-10$ & 10 & 97.5 & 93.7 & $23.9 \pm 3.3$ & $\begin{array}{c}86.4 \pm \\
3.3\end{array}$ & $5.3 \pm 0.3$ & $8.4 \pm 3.2$ & 1.6 & $8.5 \pm 0.1$ & $46.0 \pm 14.1$ & $3227.2 \pm 367.1$ \\
\hline $11-25$ & 20 & 79.2 & 70.6 & $42.6 \pm 7.1$ & $\begin{array}{c}47.1 \pm \\
9.6\end{array}$ & $13.8 \pm 2.4$ & $39.1 \pm 7.9$ & 2.8 & $8.1 \pm 0.1$ & $59.6 \pm 3.8$ & $2877.2 \pm 109.9$ \\
\hline $26-35$ & 15 & 97.1 & 87.5 & $28.7 \pm 2.0$ & $\begin{array}{c}83.1 \pm \\
3.4\end{array}$ & $8.8 \pm 0.7$ & $8.1 \pm 3.0$ & 0.9 & $8.3 \pm 0.1$ & $44.1 \pm 7.5$ & $3237.1 \pm 62.0$ \\
\hline $36-45$ & 20 & 94.5 & 85.6 & $30.1 \pm 2.6$ & $\begin{array}{c}75.9 \pm \\
7.5\end{array}$ & $9.6 \pm 1.1$ & $14.5 \pm 6.6$ & 1.5 & $8.3 \pm 0.1$ & $36.5 \pm 4.1$ & $3208.6 \pm 134.6$ \\
\hline
\end{tabular}

\subsection{Microbial communities}

The performed microbial communities analysis indicated that in both TBR configurations, the hydrogenotrophic methanogens such as Methanobacterium and Methanothermobacter were prevailing during the whole experimental period (Fig. 5). Both genera belong to the family Methanobaceteriaea that can mediate the hydrogenotrophic methanogenesis both under mesophilic and thermophilic conditions. Similar findings have been published in previous studies, where Methanobacterium was reported as prevailing 12,23,24. The sum of Methanobacterium and Methanobacter at the concurrent reactor ranged from 57.8 to $67.3 \%$ while for counter-current reactor it ranged from 69.8 to $84.9 \%$. The Methanobacterium genus was prevailing during both counter-current and concurrent operation of TBR (share from 45.7 to 64.9). Its relative share during the experimental period was rather stable in counter-current TBR, while it tended to decrease in time at concurrent configuration.

In both configurations, the second hydrogenotrophic methanogen, Methanothermobacter, had a same tendency to increase its relative share over time. It increased from $4.9-24.8 \%$ in counter-current TBR while from $0.1-21.6 \%$ in concurrent configuration. It can be hypothesized that late Methanothermobacter development was correlated to its potential slower growth rate compared to Methanonobacterium or due to the applied high gas loading rates ${ }^{30}$.

Acetoclastic methanogens nearly not detected during this work. The presence of acetoclastic methanogens such as Methnosarcina genus was detected only once at the counter-current TBR at day 
45. Its relative share was $1.3 \%$ and could be connected to the lower performance (effluent $\mathrm{CH}_{4} 68.5 \pm$ $4.5 \%)$.

Regarding bacterial genera, the genus Pseudomonas was found at a significant share. It had a lower share at the counter-current TBR that was $<10 \%$ and ranged from 0.1 to $6.4 \%$. Their higher presence was found in concurrent TBR that ranged from 1.9 to $16.5 \%$. This high relative share of Pseudomonas contradicts (day 20 in concurrent TBR) with the period of low $\mathrm{CH}_{4}$ production (average $47.1 \pm 9.6 \%$ ) and the highest concentration of acetic acid in the liquid phase $(63.8 \mathrm{mg} / \mathrm{L})$. Pseudomonas are facultative anaerobic bacteria and are capable to proliferate with nitrate as electro acceptor under anoxic conditions.

31 . The presence of Pseudomonas was previously reported in relation to AD where its role was indicated as to be responsible for carbohydrates hydrolysis independently of substrate and process parameters or in degradation of lipids to produce fatty acids ${ }^{32,33}$. However, their role was not correlated to homoacetogenesis. Therefore, the role of Pseudomonas and its occasional enrichment during this work is unknown and can be only correlated to the higher levels of acetic acid level in the liquid phase of concurrent TBR. However, the same relationship cannot be drawn for counter-current configuration where the acetic acid presence was decreasing in time. In response to that, the future studies supposed to focus on the role of Pseudomonas or other bacteria during the ex-situ biomethanation. This could be potentially achieved by analyses of nitrogen in liquid phase or lipids/carbohydrates degradation.

\section{Conclusions}

The counter-current TBR achieved better performance compared to concurrent configuration giving $96.1 \pm$ $2.5 \%$ of $\mathrm{CH}_{4}$ at gas loading $10 \mathrm{~m}^{3} / \mathrm{m}^{3} / \mathrm{d}\left(86.4 \pm 3.3 \%\right.$ of $\mathrm{CH}_{4}$ in concurrent TBR). Higher loadings had no effect on the performance of counter-current TBR, giving lower $\mathrm{CH}_{4}$ content at stable manner $(68.5 \pm 2.5 \%$ at $30 \mathrm{~m}^{3} / \mathrm{m}^{3} / \mathrm{d}$ ). Unstable performance was observed for concurrent configuration at gas loadings $>15$ $\mathrm{m}^{3} / \mathrm{m}^{3} / \mathrm{d}$ that decreased $\mathrm{CH}_{4}$ production (until liquid phase exchange) and increased acetic acid presence in liquid phase. Hydrogenotrophic methanogens with dominating Methanobacterium (45.7$64.9 \%$ ) and second Methanothermobacter had a prevailing share in microbial communities of both configurations.

\section{Declarations}

\section{Funding}

These studies were supported by the Research Council of Norway through the Bio4Fuels project (no. 257622) and NorBioLab (no. 270038).

\section{Authors contribution}


MS wrote the main manuscript text and interpretated data. All authors (MS, RW) reviewed the manuscript, performed, and designed the experiment.

\section{Acknowledgments}

The authors would like to thank Roald Aasen, Hege Bergheim, Keno Fischer, and Rikard Petersen for help in the experimental setup preparation.

\section{References}

1. Sinsel, S. R., Riemke, R. L. \& Hoffmann, V. H. Challenges and solution technologies for the integration of variable renewable energy sources-a review. Renew. Energy 145, 2271-2285 (2020).

2. Liebetrau, J., Kornatz, P., Baier, U., Wall, D. \& Murphy, J. D. Integration of Biogas Systems into the Energy System: Technical aspects of flexible plant operation. IEA Bioenergy Task vol. 37 (2020).

3. Alitalo, A., Niskanen, M. \& Aura, E. Biocatalytic methanation of hydrogen and carbon dioxide in a fixed bed bioreactor. Bioresour. Technol. 196, 600-605 (2015).

4. Miltner, M., Makaruk, A. \& Harasek, M. Review on available biogas upgrading technologies and innovations towards advanced solutions. J. Clean. Prod. 161, 1329-1337 (2017).

5. Niesner, J., Jecha, D. \& Stehlík, P. Biogas upgrading technologies: state of art review in European region. Chem. Eng. Trans. 35, 517-522 (2013).

6. Khan, I. U. et al. Biogas as a renewable energy fuel-A review of biogas upgrading, utilisation and storage. Energy Convers. Manag. 150, 277-294 (2017).

7. Angelidaki, I. et al. Biogas upgrading and utilization: Current status and perspectives. Biotechnol. Adv. 36, 452-466 (2018).

8. Strübing, D. et al. Anaerobic thermophilic trickle bed reactor as a promising technology for flexible and demand-oriented H2/CO2 biomethanation. Appl. Energy 232, 543-554 (2018).

9. Kougias, P. G. et al. Biological $\mathrm{CO} 2$ fixation in up-flow reactors via exogenous $\mathrm{H} 2$ addition. J. Biotechnol. 319, 1-7 (2020).

10. Strübing, D., Huber, B., Lebuhn, M., Drewes, J. E. \& Koch, K. High performance biological methanation in a thermophilic anaerobic trickle bed reactor. Bioresour. Technol. 245, 1176-1183 (2017).

11. Rachbauer, L., Voitl, G., Bochmann, G. \& Fuchs, W. Biological biogas upgrading capacity of a hydrogenotrophic community in a trickle-bed reactor. Appl. Energy 180, 483-490 (2016).

12. Porté, H. et al. Process performance and microbial community structure in thermophilic trickling biofilter reactors for biogas upgrading. Sci. Total Environ. 655, 529-538 (2019).

13. APHA. Standard methods for the examination of water and wastewater, 23rd ed. American Water Works Association (Washington, DC, USA, 2017).

14. Albertsen, M., Karst, S. M., Ziegler, A. S., Kirkegaard, R. H. \& Nielsen, P. H. Back to basics-the influence of DNA extraction and primer choice on phylogenetic analysis of activated sludge communities. 
PLoS One 10, e0132783 (2015).

15. Apprill, A., McNally, S., Parsons, R. \& Weber, L. Minor revision to V4 region SSU rRNA $806 \mathrm{R}$ gene primer greatly increases detection of SAR11 bacterioplankton. Aquat. Microb. Ecol. 75, 129-137 (2015).

16. Edgar, R. C. UPARSE: highly accurate OTU sequences from microbial amplicon reads. Nat. Methods 10, 996-998 (2013).

17. Caporaso, J. G. et al. QIIME allows analysis of high-throughput community sequencing data. Nat. Methods 7, 335 (2010).

18. Wang, Q., Garrity, G. M., Tiedje, J. M. \& Cole, J. R. Naive Bayesian classifier for rapid assignment of rRNA sequences into the new bacterial taxonomy. Appl. Environ. Microbiol. 73, 5261-5267 (2007).

19. Quast, C. et al. The SILVA ribosomal RNA gene database project: improved data processing and webbased tools. Nucleic Acids Res. 41, D590-D596 (2012).

20. Ryckebosch, E., Drouillon, M. \& Vervaeren, H. Techniques for transformation of biogas to biomethane. Biomass and Bioenergy 35, 1633-1645 (2011).

21. Strübing, D. et al. Load change capability of an anaerobic thermophilic trickle bed reactor for dynamic H2/CO2 biomethanation. Bioresour. Technol. 289, 121735 (2019).

22. Burkhardt, M., Koschack, T. \& Busch, G. Biocatalytic methanation of hydrogen and carbon dioxide in an anaerobic three-phase system. Bioresour. Technol. 178, 330-333 (2015).

23. Ashraf, M. T. et al. Biomethanation in a thermophilic biotrickling filter $-\mathrm{pH}$ control and lessons from long-term operation. Bioresour. Technol. Reports 11, 100525 (2020).

24. Dahl Jønson, B. et al. Direct inoculation of a biotrickling filter for hydrogenotrophic methanogenesis. Bioresour. Technol. 318, 124098 (2020).

25. Rusmanis, D. et al. Biological hydrogen methanation systems - an overview of design and efficiency efficiency. Bioengineered 10, 604-634 (2019).

26. Kougias, P. G., Campanaro, S., Treu, L., Zhu, X. \& Angelidaki, I. A novel archaeal species belonging to Methanoculleus genus identified via de-novo assembly and metagenomic binning process in biogas reactors. Anaerobe 46, 23-32 (2017).

27. Ye, R., Jin, Q., Bohannan, B., Keller, J. K. \& Bridgham, S. D. Homoacetogenesis: A potentially underappreciated carbon pathway in peatlands. Soil Biol. Biochem. 68, 385-391 (2014).

28. Mclnerney, M. J. \& Bryant, M. P. Basic principles of bioconversions in anaerobic digestion and methanogenesis. in Biomass Conversion Processes for Energy and Fuels 277-296 (1981).

29. Saady, N. M. C. Homoacetogenesis during hydrogen production by mixed cultures dark fermentation: Unresolved challenge. Int. J. Hydrogen Energy 38, 13172-13191 (2013).

30. Mauerhofer, L.-M. et al. Hyperthermophilic methanogenic archaea act as high-pressure $\mathrm{CH} 4$ cell factories. Commun. Biol. 4, 1-12 (2021).

31. Li, Y., Zhang, W. \& Xu, J. Siloxanes removal from biogas by a lab-scale biotrickling filter inoculated with Pseudomonas aeruginosa S240. J. Hazard. Mater. 275, 175-184 (2014). 
32. Buettner, C., von Bergen, M., Jehmlich, N. \& Noll, M. Pseudomonas spp. are key players in agricultural biogas substrate degradation. Sci. Rep. 9, 1-13 (2019).

33. Potivichayanon, S., Sungmon, T., Chaikongmao, W. \& Kamvanin, S. Enhancement of biogas production from bakery waste by Pseudomonas aeruginosa. Int. J. Chem. Mol. Eng. 5, 655-658 (2011).

\section{Figures}

(a)

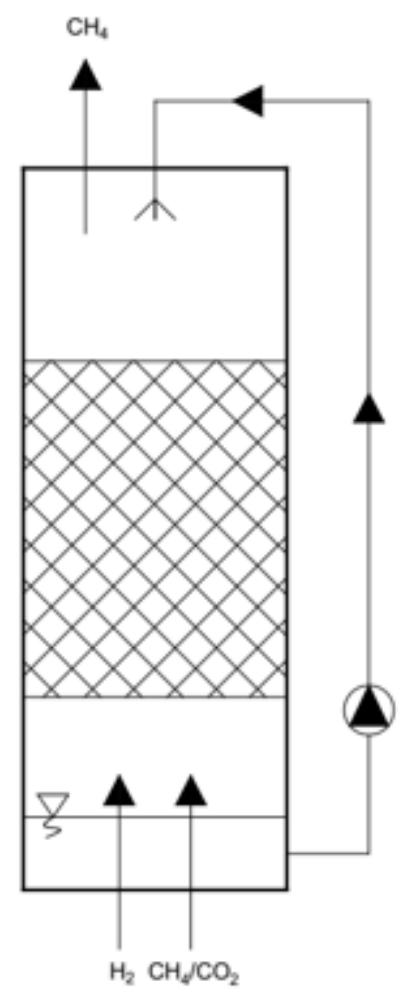

(b)

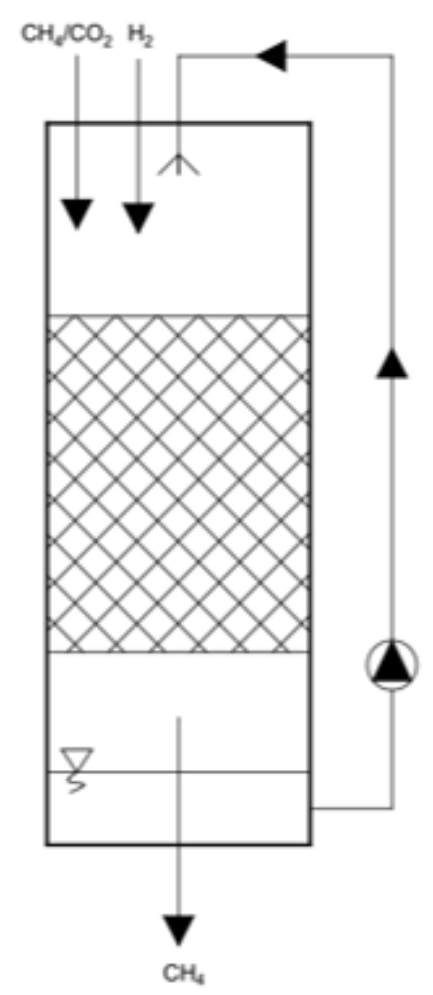

\section{Figure 1}

Trickle bed reactor configurations: (a) counter-current, (b) concurrent. 

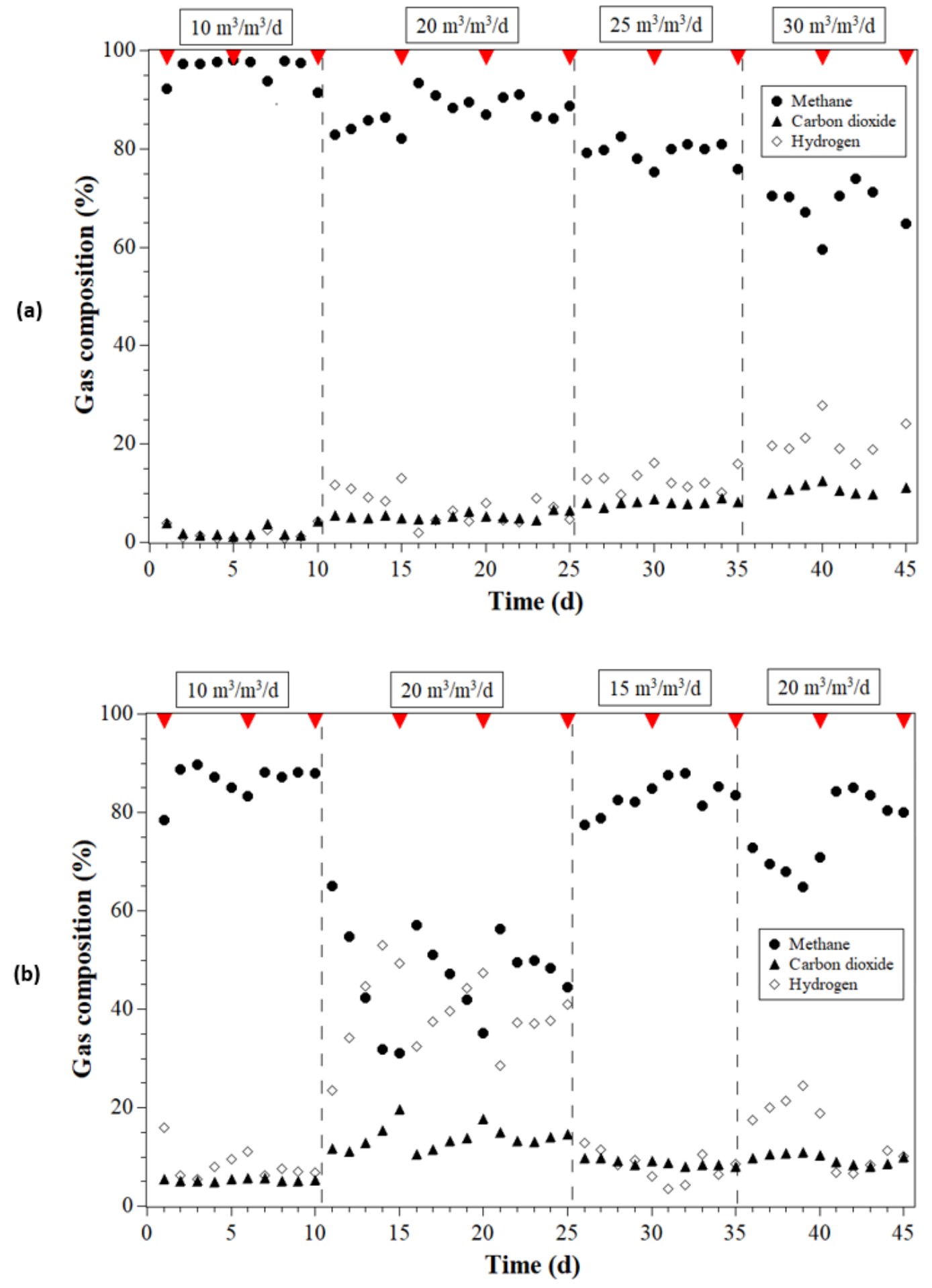

Figure 2

Effluent gas composition during the continuous operation of TBR (a) counter-current, (b) concurrent; the inverted triangles indicate liquid phase replacement, and sample collection. 
(a)

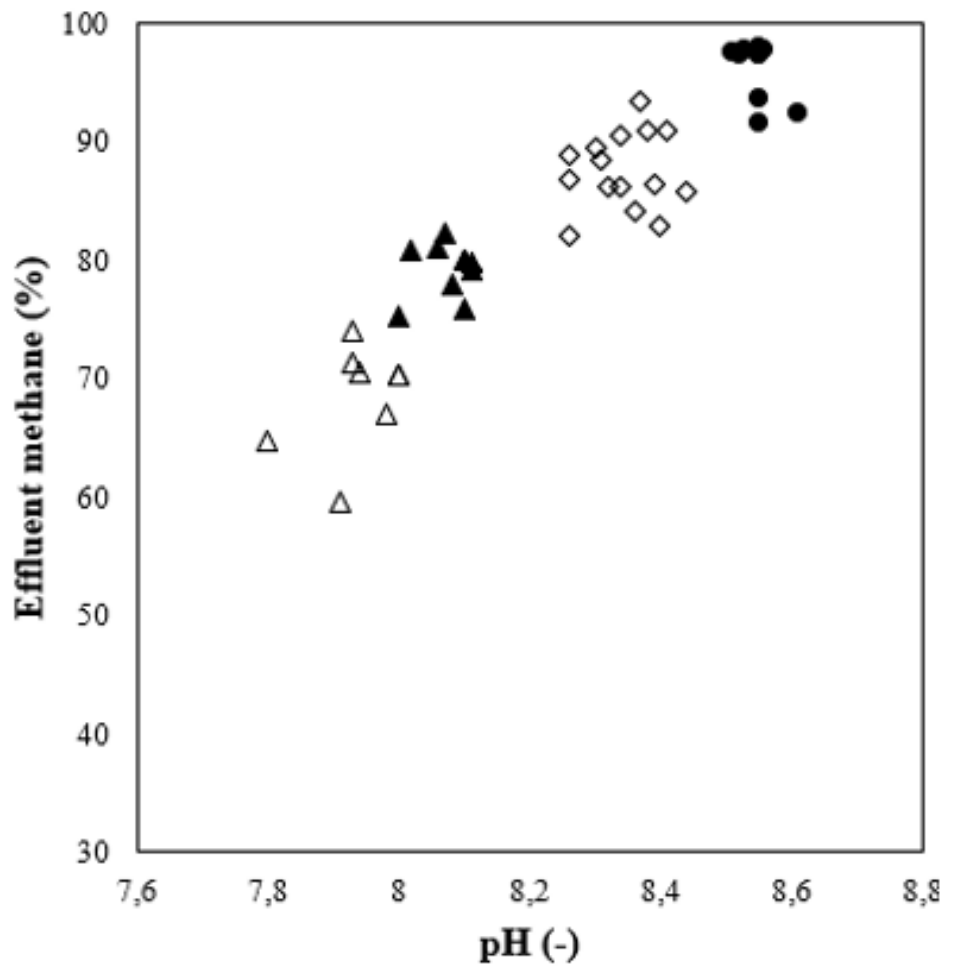

(b)

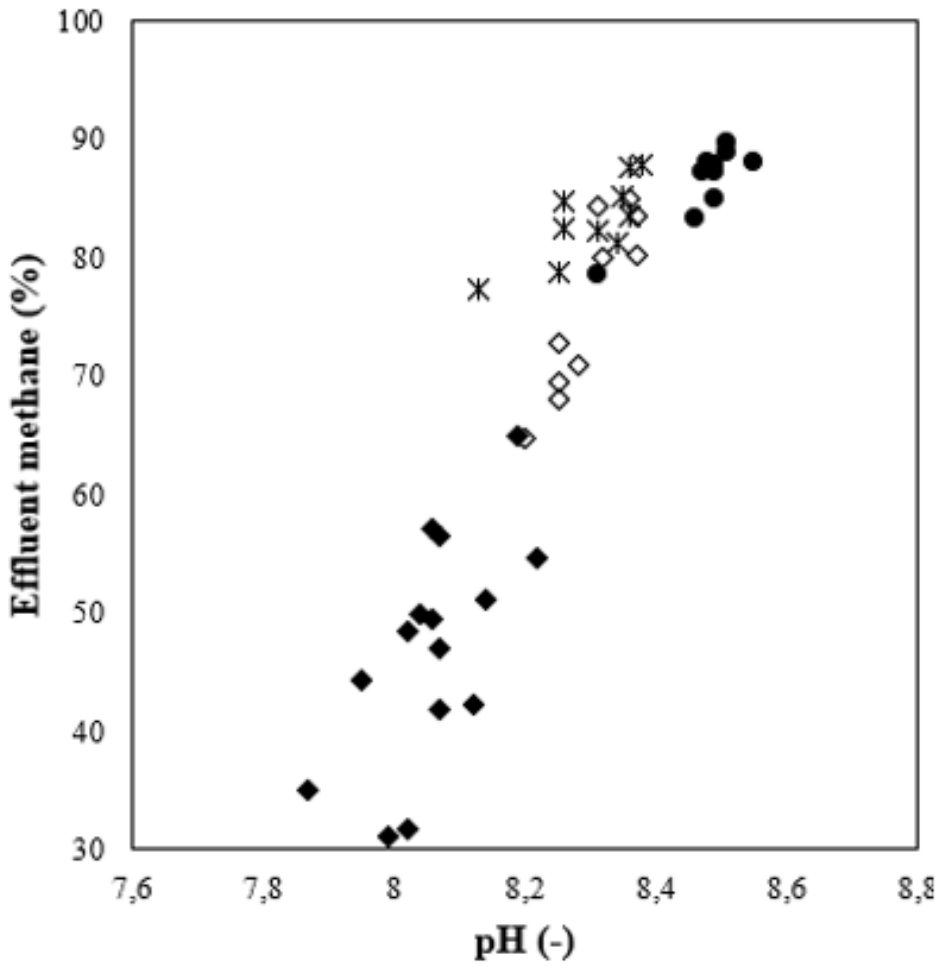

Figure 3

Relationship between pH and effluent $\mathrm{CH} 4$ concentration for (a) counter-current and (b) concurrent TBR; symbols indicate different gas loading rates: $-10, \nabla-15, \nabla-20, \nabla-20$ (for concurrent days 11-25), $\mathbf{\Delta}-25$ and $\Delta-30 \mathrm{~m} 3 / \mathrm{m} 3 / \mathrm{d}$. 
(a)

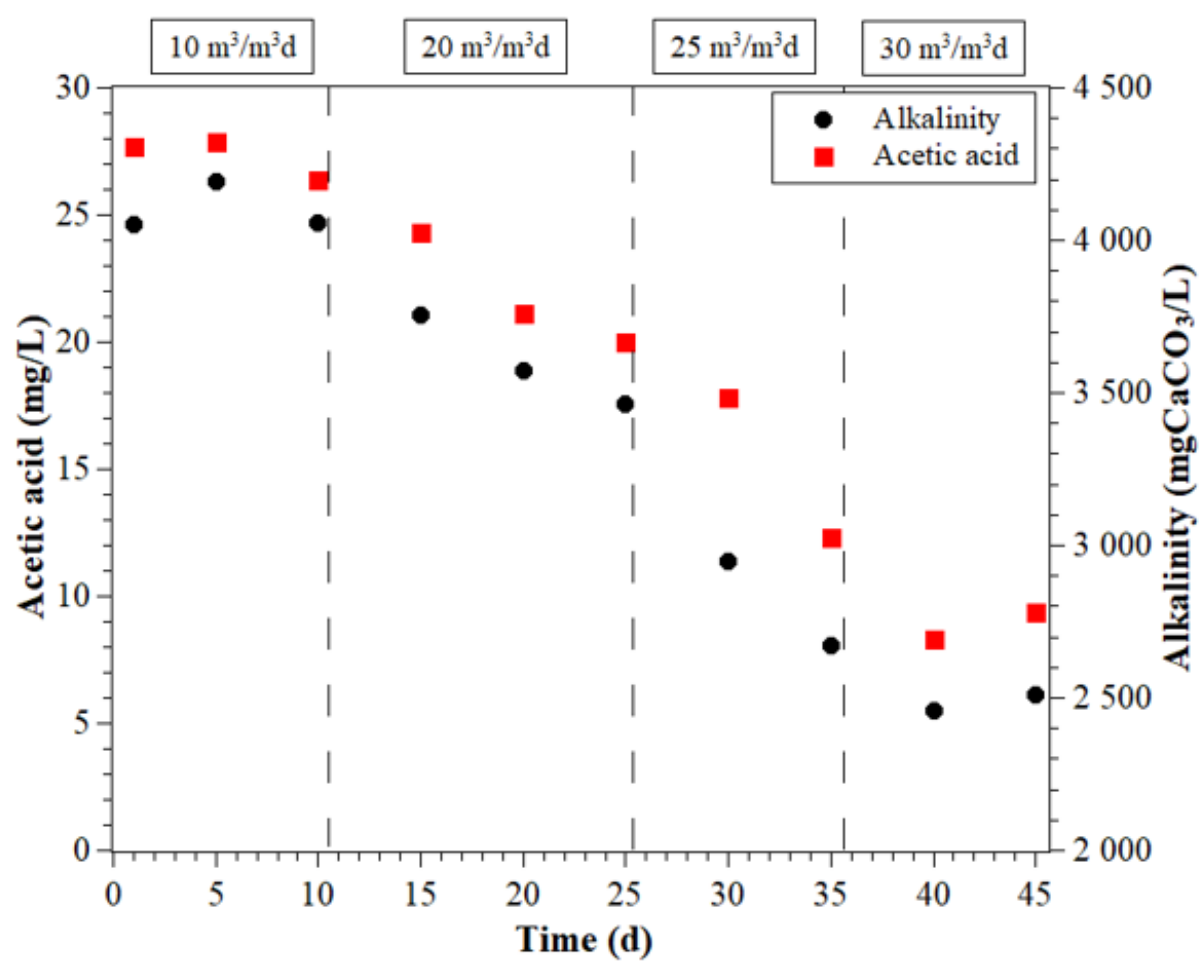

(b)

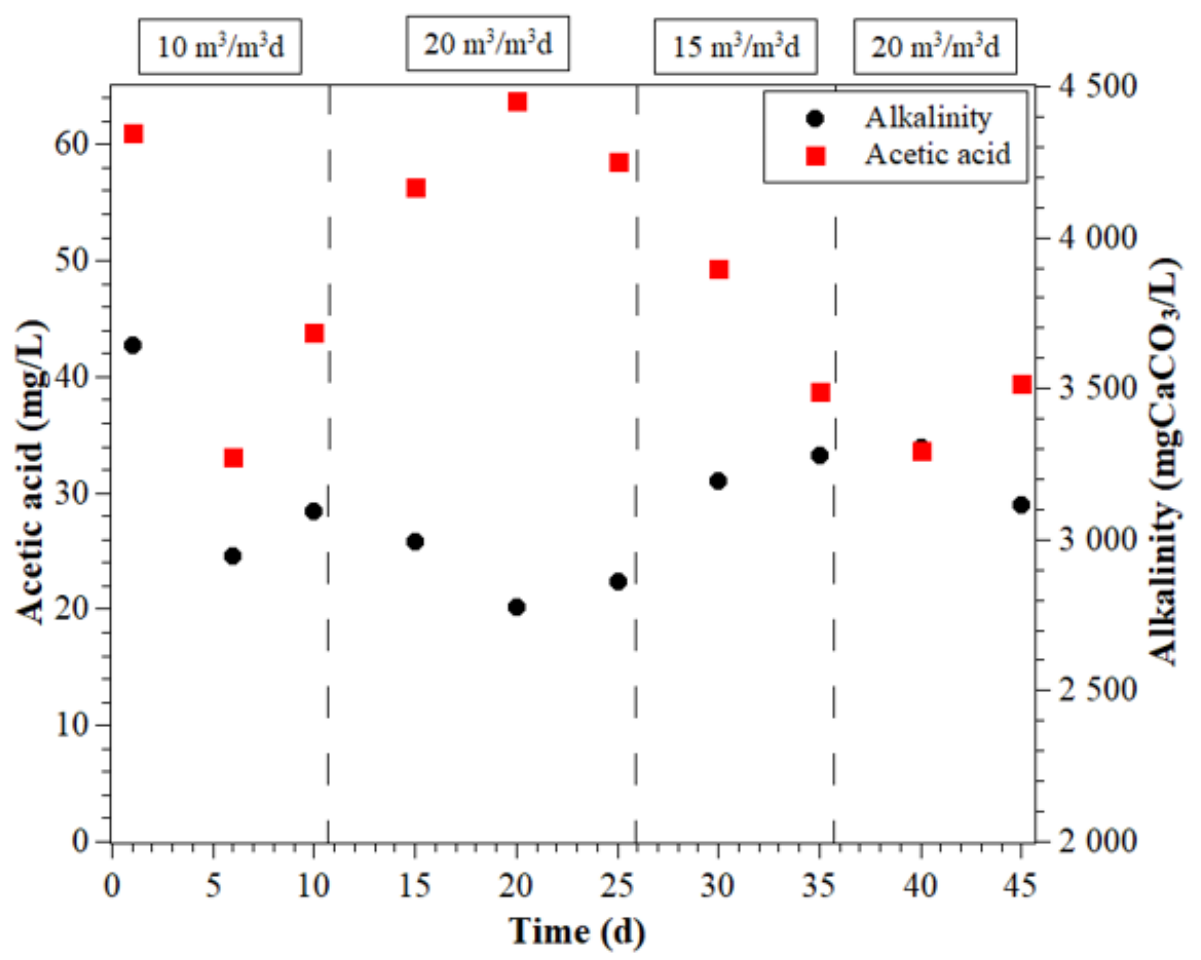

Figure 4

Alkalinity level and acetic acid presence in the liquid phase of (a) counter-current and (b) concurrent TBR. 
(a)

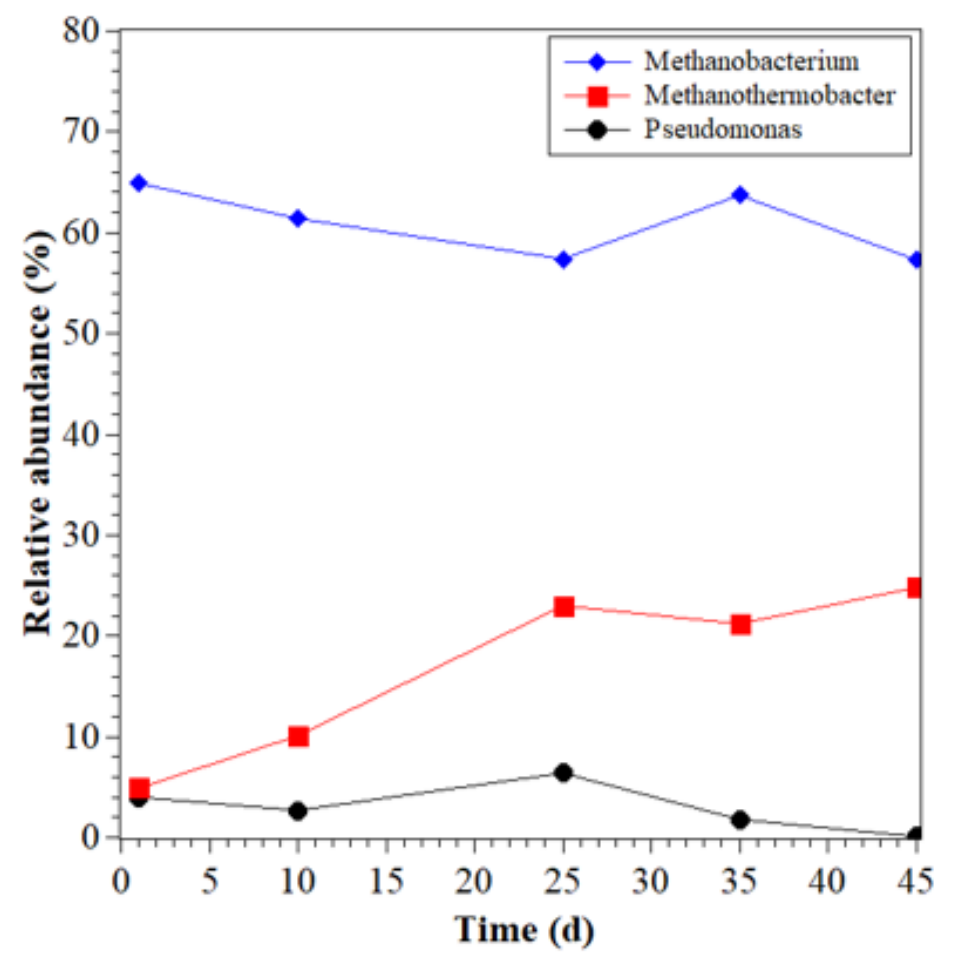

(b)

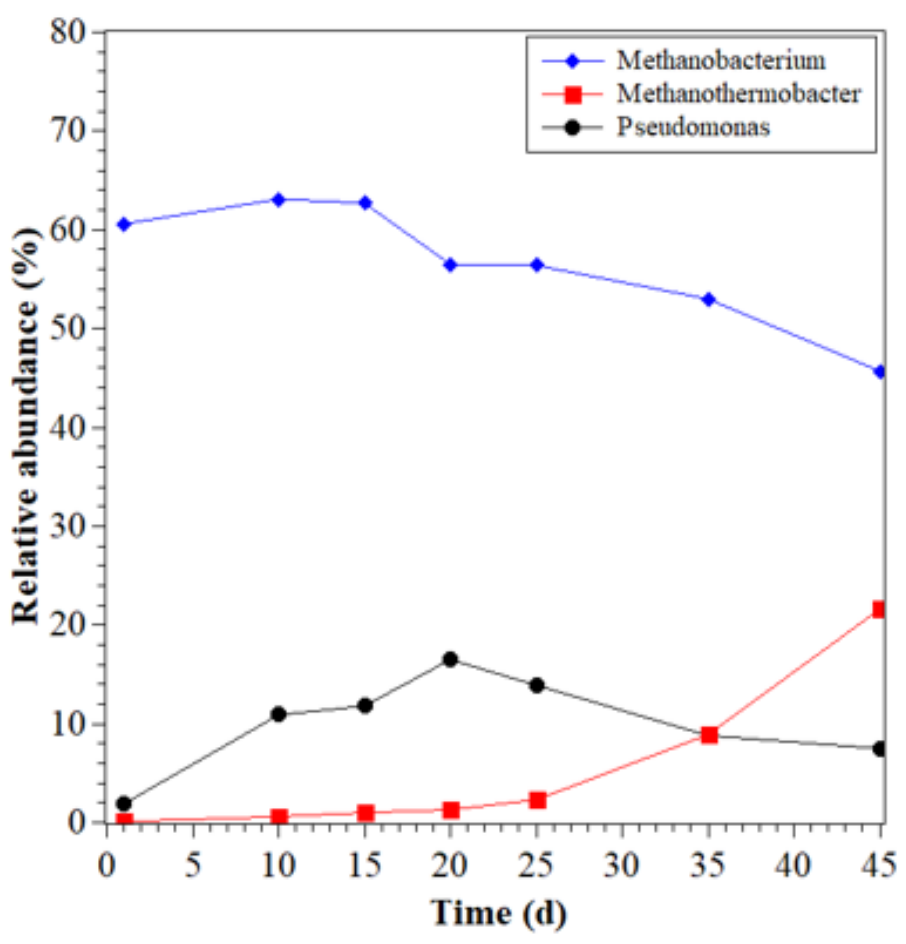

Figure 5

Most abundant genera in (a) counter-current and (b) concurrent TBR (the complete information about all detected genera is given in Supplementary Materials).

\section{Supplementary Files}

This is a list of supplementary files associated with this preprint. Click to download.

- Supplementarymaterials.docx 